TURIZAM

Volume 19, Issue 4 $165-182(2015)$

ORIGINAL SCIENTIFIC PAPER

\title{
Tourists' Satisfaction at Trijuginarayan: An Emerging Spiritual and Adventure Tourist Destination in Garhwal Himalaya India
}

\author{
S.C. Bagri*, Devkant Kala** \\ Received: June 2015| Accepted: September 2015
}

\begin{abstract}
Tourists' satisfaction has been acknowledged as one of the most important elements of competitive advantage and formulating effective destination management strategies because it is a reliable standard to evaluate performance of tangible and intangible elements of tourism products and services. The purpose of this study is to investigate tourists' satisfaction by examining the relationship between destination attribute importance and performance in a tourist destination. Trijuginarayan, an emerging spiritual and adventure tourist destination located in Garhwal Himalaya in Uttarakhand state of India was selected as the study area for this research. Importance-Performance Analysis was employed to examine the relationship between importance and performance of various destination attributes. Results revealed that attributes related to tourism product of spiritual and cultural nature, atmosphere and climate, a variety of tourist activities, hospitality and safety are significant factors in determining tourist satisfaction, whereas basic facilities such as accommodation, transportation, tourism infrastructure and hygiene and sanitation at destination are of significant importance in satisfaction evaluation. Findings also reveal that tourists were satisfied with the core products, but were dissatisfied with basic tourist facilities offered at the destination. The findings alert concerned tourism stakeholders for outlining effective strategies for holistic development and improving performance of attributes in a given destination.
\end{abstract}

Keywords: Tourist Satisfaction, Importance-Performance Analysis, India.

\section{Introduction}

Tourist satisfaction is assumed as one of the crucial elements for a superior advantage, distinctive image and market destinations successfully, as it influences the choice of destination, consumption of products and services, decide to return, maintain long term relationship and improve destination reputation (Kozak and Rimmington, 2002; Yoon and Uysal, 2005; Zabkar et al., 2010; Osti et al. 2012). Tourist satisfaction is a feeling generated both by cognitive and

* Centre for Mountain Tourism and Hospitality Studies, HNB Garhwal Central University, Srinagar (Garhwal), Uttarakhand, India, Corresponding author: prof.bagri@gmail.com

** Department of Management, Uttaranchal University, Dehradun, Uttarakhand, India, email:devkala@gmail.com 
emotional aspects of tourism activities, as well as an accumulated evaluation of various components and features of the visiting destination (Wang et al, 2009). It primarily refers to the result of relationship between tourists' expectations about the destination based on their previous information and image of the destination (pre-travel expectations) and their assessment of the outcome of their experience (post-travel experiences) at the visiting destination (Pizam, Neumann and Reichel, 1978; Neal and Gursoy, 2008; Bigne et al., 2009; McDowall, 2010). Measuring tourist satisfaction provides information about how well a destination matches the tourists' needs, which may help destination stakeholders to improve quality of products/services that interest tourists (Meng, Tepanon and Uysal, 2008). It also helps tourism authorities and entrepreneurs to identify strategic objectives at the destination level, to prepare tactical and operational plans, and to increase the competitiveness of a given destination (Huang and Xiao, 2000; Hui et al., 2007; Dmitrovic et al., 2009; Christou and Saveriades, 2010).

As tourist satisfaction influences tourist behavioral intentions and plays a vital role in destination competitive advantage, it has attracted scholars' interest and a large number of articles and studies have focused on this aspect with regard to various tourist destinations throughout the world (Pizam, Neumann and Reichel, 1978; Baker and Crompton, 20oo; Huang and Xiao, 2000; Kozak and Rimmington, 2000; Kozak 2001; Yoon and Uysal, 2005; Wang and Qu, 2006; Hui et al., 2007; Chi and Qu, 2008; Cracoli and Nijkamp, 2008; Neal and Gursoy, 2008; Dmitrovic et al, 2009; Alegre and Garau, 2010; Chen and Chen, 2010; Christou and Saveriades, 2010; Marcussen, 2011; Osti et al. 2012). Uttarakhand State of India has received poor coverage in literature, despite of having the excellent pilgrimage places. Studies can be found on ecotourism (Bagri et al, 2013), tourism resources planning and management (Singh, 2005), pilgrimage tourism (Thapliyal, 2006), sustainable tourism (Kaul and Gupta, 2009), tourism education (Bagri and Babu, 2011), trekking tourism (Reuter and Pechlaner, 2012), human resource practices (Bagri et al., 2010, 2011), community attitude (Singh et al., 2009), performance measurement (Kala and Bagri, 2014), but little work has been undertaken to measure tourist satisfaction in Uttarakhand (Uttarakhand Tourism Development Master Plan, 2007-2022, 2008; Mahar and Bagri, 2010; Masarrat, 2012; Singh and Singh, 2009). The dearth of research conducted in the tourist satisfaction in Uttarakhand has prompted researchers to conduct survey on satisfaction of tourists in the study area. The present study adds in the area of tourist satisfaction by providing an empirical relationship between destination attribute importance and performance as perceive by tourists and overall tourist satisfaction.

\section{The Study Area: Trijuginarayan}

Uttarakhand state is located in the northern part of India sharing international boundary with Nepal and Tibet (China) and national boundary with Himachal Pradesh and Uttar Pradesh State of India. Uttarakhand state has a rich cultural heritage and is famous for nature, wildlife, pilgrimages, yoga and meditation, mountains, peaks and forests, valleys, glaciers, rivers, flora and fauna, Hindu religion pilgrimage sites like Badrinath and Kedarnath, the world heritage site Nanda Devi Biosphere Reserve, and the first national park of India - Jim Corbett National Park. Situated at a distance of $249 \mathrm{~km}$ from Uttarakhand state capital Dehradun and $460 \mathrm{~km}$ from national capital New Delhi, Trijuginarayan enjoys the privilege of having a rich background of tourism elements. The destination is unique in its natural surroundings and has all the qualities to attract high-value rural tourists, potential to successfully compete with other Himalayan destinations, and generate a substantial income to local people. The study area is easily reachable by 
road from Delhi, the national capital of India and other major cities of Northern India. Adequate rail and air transportation facilities are available up to state capital Dehradun. Triguninarayan is located at an altitude of 1,980 meters, which gives the region an enjoyable weather round the year. Summers are pleasant and the temperature ranges between a comfortable $15^{\circ} \mathrm{C}-30^{\circ} \mathrm{C}$. The study area experiences moderate rainfalls in the months of July and August, which bring freshness and rejuvenating greenery to the place. Winters are extremely cold here with the temperature diving down to a chilling $0^{\circ} \mathrm{C}-15{ }^{\circ} \mathrm{C}$. The most appropriate time to visit Trijuginarayan is either between March to June or September to November.

Owing to its religious significance and natural surroundings, it has been declared a tourist village by the Uttarakhand State Government. According to legendary accounts, it is believed that the marriage of Lord Shiva (one of the trinities of Hindu Gods) and Goddess Parvati (one of the forms of Durga, treated mother Goddess in Hindu religion) is solemnized here in Treta Yug (it is believed that this period belongs to millions of years back when Load Rama ruled India) in the presence of Lord Vishnu (one of the trinities of Hindu Gods). Because of this Lord Vishnu is being worshipped here continuously throughout three yugas (One yug is equal to millions of years), thus it is named Trijuginarayan. Encircled by abundant foliage, the temple represents Pahri-Partihar architecture style, gives a picture of the rich built heritage of Garh-
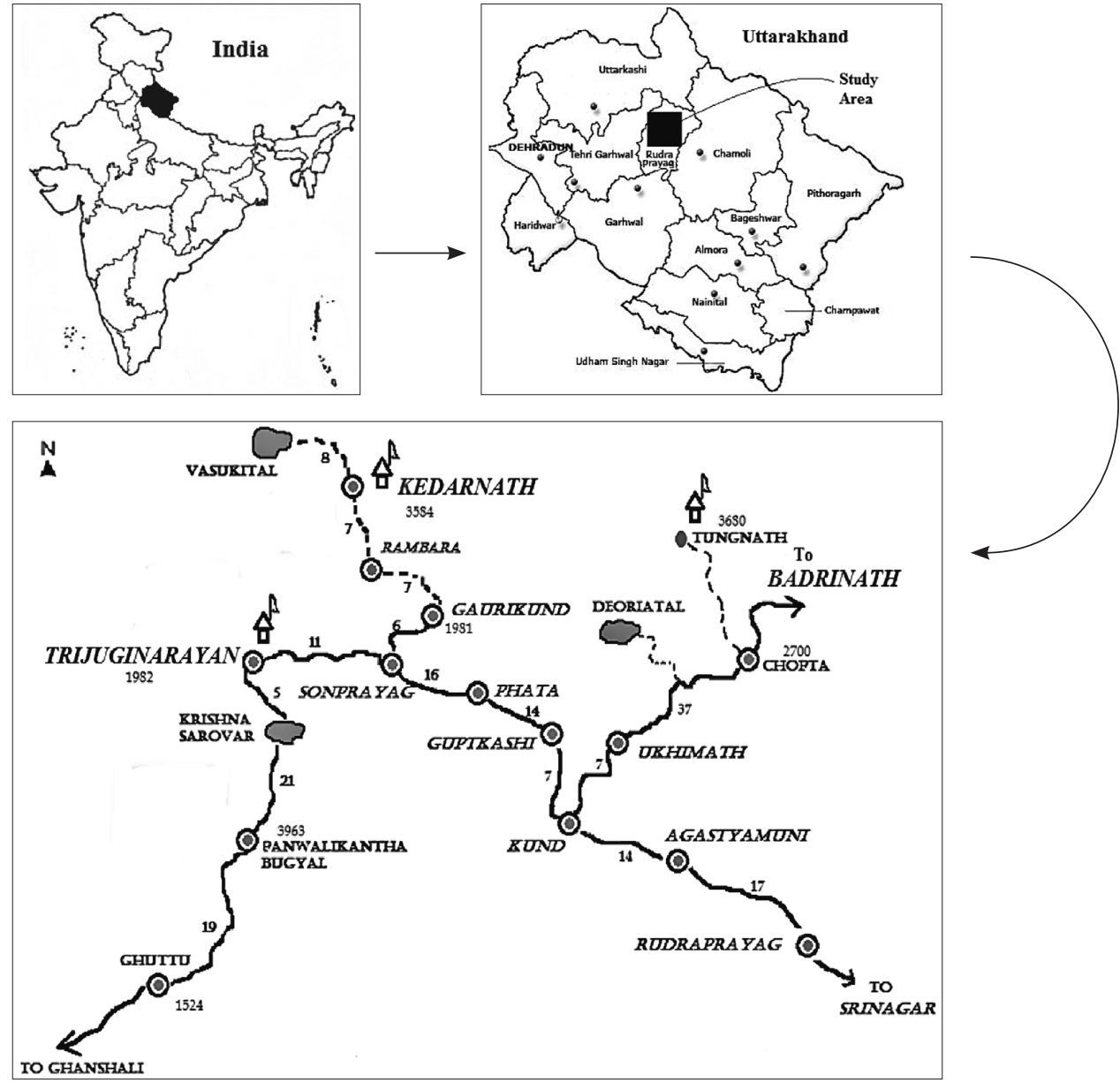

Figure 1. Roadmap of Trijuginarayan 
wal region. On being accessible to Kedarnath, Vasukital and Panwalikantha mountain meadow, Trijuginarayan has become a familiar tourist destination for all nature of the tourists. As per the information shared by local people, Trijuginarayan receives around 9 to 10 thousand pilgrims and tourists from May to October every year.

Trijuginarayan is an ideal destination for promoting spiritual tourism owing to its natural and cultural surroundings. Vishnu temple of Trijuginarayan is the main attraction. Vishnu Kund, Rudra Kund, Brahma Kund (Kund is local name and is almost similar to purified water tank like of spa), Aachhri Udiyar (Udiyar is the local name of rock shelter), Gauri Gufa (Cave) and Krishna Sarovar (Lake) and Chandika temple are other notable attractions. Numerous trek routes, originating from Trijuginarayan, are ideally designed to suit the needs of tourists in terms of visitation, use pattern and other interrelated tourist activities. In view of its natural bounty, rich spiritual values and emerging adventure tourism opportunities, the region is growing rapidly and people of surrounding locations and nearby states has started to visit these attractions to visualize religious heritage and to enjoy adventurous activities on this unexplored site. The study area offers many opportunities to explore temple architecture, lakes and caves, $360^{\circ}$ view of Himalayan peaks and Mandakini river valley, trekking trail, rock climbing, rappelling, Paragliding, nature photography and cycle safari.

\section{Objectives of the study}

In order to examine the level of tourist satisfaction, the present study has following objectives:

- To investigate tourists' satisfaction in an emerging spiritual and adventure tourism destination;

- To identify tourists' likings and dislikings through importance-performance approach; and

- To suggest meaningful services to make the study area preferable tourist destination.

\section{Literature Review}

Enhancing tourist satisfaction is one of the primary functions of tourism destination and a prerequisite for the development of strategies leading to destination's improved attractiveness and competitive positioning (Dmitrovic et al, 2009). In recent years, the term tourist satisfaction has become a priority research area for developing tools and models to measure and monitor performance of tourist destinations. Although tourist satisfaction is a personal judgment, the understanding of tourists' satisfaction is necessary for evaluating the performance of the destination, improving products and services offered, promoting tourism offerings effectively to target markets, gaining better destination image, and determine repeat visits and predisposition for recommending the destination to others (Kozak and Rimmington, 2000; Yuksel, 2001; Yoon and Uysal, 2005; Chi and Qu, 2008; Meng, Tepanon and Uysal, 2008). Satisfied tourists normally recommend better tourist destinations to others or express their appreciation about the destination and are keen to visit again and vice-versa (Baker and Crompton, 2000; Kozak and Rimmington, 2000; Bigne et al. 2001; Chen and Tsai, 2007; Meng, Tepanon and Uysal, 2008; Bigne et al., 2009; Lee, 2009; Zabkar et al., 2010; Marcussen, 2011). Dissatisfied tourists may express negative comments about a destination causing set back to its market reputation (Chen and Chen, 2010). It is also observed when tourists visit a destination; they seek more than one experience at the given destination. They stay in a hotel, go outside the 
hotel to eat and drink, communicate with local people and visit cultural and historical sites. A trip becomes not a single product, but rather consists of different service components often provided by multiple organizations with different objectives (Kozak, 2003; Ozturk and Qu 2008). It is important to identify and measure tourist satisfaction with each attribute that a destination offer as the level of satisfaction or dissatisfaction with one of the attributes leads to satisfaction or dissatisfaction with overall destinations.

Kozak and Rimmington (200o) study in Mallorca, Spain, reveal that various variables of destination attractiveness, tourist attractions and facilities and services at the destination airport were significant in determining overall tourist satisfaction. Respondent's intention to repeat their visits to Mallorca in the future was influenced by destination attractiveness, facilities and services at the destination airport, and the level of overall satisfaction of visiting tourists. Kozak (2003) measures tourist satisfaction with multiple destination attributes and the subsequent intention to repeat visitation and recommend to others among four different groups of tourists visiting two different destinations: Mallorca, Spain and Mugla, Turkey. The results of this study show that overall tourist satisfaction, intention to recommend and intention to repeat visit were affected by multiple attributes and differ from one customer group and from one destination to another. Pritchard (2003) researched about attitudinal and behavioral consequences of destination performance. This study surveyed visitors to Western Australia and used factor analysis to develop two performance-expectation measures of the destination's environment and service infrastructure. The result revealed that destination performance is not only an important factor, but also their behavior such word of mouth affecting tourists' satisfaction as well as intending to return. Yoon and Uysal (2005) examined causal relationships among push and pull motivations, satisfaction and destination loyalty using structural equation modeling in Northern Cyprus. The study identified tourist relaxation, family togetherness, knowledge \& education of historical places and new people, cleanness and shopping, and safety and fun appeal the most to tourists' motives to travel and satisfaction. It recommended managers to establish a higher tourist satisfaction level to create positive post-purchase tourist behavior, in order to improve and sustain destination competitiveness.

Wang and Qu (2006) study on tourist satisfaction was based upon variables such as accommodations, shopping opportunities, restaurant facilities, quality of accommodation, personal safety, tourist information, road conditions, potable water, and traffic flow and parking facilities. While evaluation tourist destination, Eureka Springs, Arkansas, USA, Chi and Qu (2008) identified seven destination attributes which generate tourist satisfaction. It includes accommodation, dining, shopping, attractions, events and activities, environment and accessibility. In one of the studies conducted in Southern Italy, Cracoli and Nijkamp (2008) categorized various factors of destination competitiveness and tourist satisfaction into two categories. Reception and sympathy of residents, artistic and cultural cities, landscape, environment and nature are "basic factors" as they characterize the comparative advantage of a tourist destination. The variables such as information and tourist services, cultural events (concerts, festivals, and art exhibitions), quality and variety of products in shops, hotels and other accommodation, the level of prices and living costs, and tourist safety are "complementary factors", as the given factors stimulate tourists to visit a destination. In perspective of Alanya, Turkey, Aktas et al. (2009) grouped all the variables influencing tourists' overall satisfaction under three titles: destination facilities, accommodation services, and incoming travel agency services. Lee (2009) proposed that destination image, attitude, motivation, natural landscapes, services and recreational opportunities are some of the notable attributes which affect tourist satisfaction. 
Alegre and Garau (2010) examined reasons of tourists' dissatisfaction at a sun and sand tourist destination in Balearic Islands, Spain. According to them the major attributes of tourist satisfaction were climate, cleanliness and hygiene, scenery, peaceful ambience, accommodation, safety, historic sites or places, the presence of friends and family, interacting with other tourist, sports activities, tourist attractions, prior visits to destination, ease of access, easy access to information, local cuisine, local lifestyle, and affordable prices. Marcussen (2011) opines that satisfaction with the accommodation is the most important determinant of overall tourist satisfaction with holidays, and satisfaction with price, facilities and offered services play a significant role in tourist satisfaction. He further adds that satisfaction is not the only factor determining intention to return. Other determinants like the accessibility of destination to the market, prior experience, socio-demographics and additional trip characteristics also play a vital role in tourist satisfaction. Prayag and Ryan (2012) describe that overall destination image, i.e. attractions, accommodation, accessibility, amenities, activities, local community and shopping of Mauritius and elaborated in detail how these factors have increased the number of tourists arriving.

Torres-Sovero et al. (2012) conducted a study on factors influencing tourist satisfaction in ecotourism lodges in the Southeastern Peruvian Amazon and noticed that the quality of the lodges, ecological features and cultural features of a destination and availability of quality of guides deployed therein played a decisive role in tourist satisfaction. The study of Khuong and Ngoc (2014) conducted from the perspective of Ho Chi Minh City, Vietnam identified factors responsible to tourists' satisfaction and research findings reveal that the higher levels of service quality, infrastructure and accessibility, natural environment, safe and security and destination image are positively associated with the higher level of tourists' destination satisfaction.

\begin{tabular}{|c|c|c|}
\hline$\frac{\sqrt[5]{0.00}}{\bar{I}}$ & Quadrant 1 & Quadrant 2 \\
\hline \& & Concentrate here & Keep up the good work \\
\hline$\underline{\varepsilon}$ & Quadrant 3 & Quadrant 4 \\
\hline 3 & Low priority & Possible overkill \\
\hline \multicolumn{3}{|r|}{ High } \\
\hline
\end{tabular}

Figure 2. Importance-Performance Analysis

Over the past few years, Importance-Performance Analysis (IPA) has attracted considerable interest. Martilla and James (1977) devised IPA as a simple graphical tool for developing effective marketing strategies based on judgments of the importance and performance of each attribute. As a part of the expectation-disconfirmation branch of literature, IPA examines the performance of an attribute and the importance of that attribute as a determining factor in satisfaction. IPA classifies mean scores into four categories to assess management priorities: 'concentrate here', 'keep up the good work', 'low priority' and 'possible overkill', allowing management to identify the areas of highest concern that warrant the use of available resources. It has been proven to be a popular management tool and is well documented in various tour- 
ism studies (Oh, 2001; Janes and Wisnom, 2003; Matzler, Sauerwein, and Heischmidt, 2003; Wade and Eagles, 2003; Zhang and Chow, 2004; Aksu, Icigen and Ehtiyar, 2010; Cheng, Guo and Ling, 2013; Chen, 2013; Medina-Muñoz, 2014; Lai and Hitchcock, 2015). This approach provides useful and easily understandable guidelines for exploring different attributes of the destination marketing mix for incorporating appropriate management action and reallocating resources according to the four areas identified to achieve competitive advantages.

\section{Research Methodology}

The sample population for this study was tourists who have stayed at least one night in Trijuginarayan during October 2011 to February 2012, as this is the prime season of tourist arrival. Each prospective participant was initially approached at selected tourist spots throughout the destination and informed about the purpose of the survey and a total of 200 tourists participated in the study. The instrument of this study was a self-administered survey questionnaire with three sections: travel behavior, tourists' satisfaction with destination attributes and demographic profile. The first part of the questionnaire examined the purpose of the visit, travel frequency, mode of transportation used, length of stay, sources of information, and companion on the trip. Second part of the questionnaire was concerned with attributes related to tourists' satisfaction with various attributes of destination. Attributes were developed based on related studies of tourist satisfaction (Kozak and Rimmington, 2000; Chi and Qu, 2008; Meng, Tepanon and Uysal, 2008; Aksu, Icigen and Ehtiyar, 2010). Respondents were asked to indicate their level of agreement with each of the 28 tourist satisfaction attributes of a fivepoint Likert- scale ranging from 1 (strongly disagree) to 5 (strongly agree). Out of 28 attributes, six were related to weather conditions and accessibility and seven were associated with the environment. Eight variables were related to quality of tourist facilities and seven were associated tourist motivational factor. The last part of the questionnaire contained questions to examine the surveyed audience demographic profile.

In order to ensure the validity, the initial questionnaire was given to a panel of experts, faculty members in the tourism and hospitality fields, to judge its validity according to its contents, the clarity of its item meaning, and suitability to avoid any misunderstanding and to assure its linkages with the main study objectives. In order to validate the reliability, the question naire was pilot tested using 30 tourists, representing $15 \%$ of the total sample size, who were considered the representatives of the study population. The value of Cronbach's alpha was found to be 0.812 , which suggested an acceptable level of reliability of the research instrument. The data thus received was systematically arranged, tabulated and analyzed. Analysis of data was performed using SPSS Statistics Version 20. 


\section{Results}

\section{Demographic Profile}

The demographic characteristics of respondents shown in table 1 reveals that $6 \%$ of respondents were from the age group of less than 21 years, $29 \%$ were from $21-35$ years, $39 \%$ were from $36-50$ years and $26 \%$ were above 50 years. The analysis indicates that males dominate the sample with $71 \%$ of them included in the survey. Male percentage is proportionately more as the region is located in isolated locations and does not appeal much to female tourist traffic. As regards to educational background, $8 \%$ tourists interviewed were $10+2,14 \%$ obtained graduate, $36 \%$ were post-graduate and $42 \%$ were having professional degree. The sample was split between married and unmarried with the majority of individuals interviewed were married (58\%). The married couple prefers to come here as this is the place wherein one of the trinities of Hindu Gods named Lord Shiva got married with his Goddess Parvati.

Table 1. Demographical Profile

\begin{tabular}{|c|c|c|c|c|c|}
\hline Age & Frequency & Percent & Qualifications & Frequency & Percent \\
\hline$<21$ Years & 12 & $6 \%$ & $10+2$ & 16 & $8 \%$ \\
\hline 21-35 Years & 58 & $29 \%$ & Graduate & 28 & $14 \%$ \\
\hline $36-50$ Years & 78 & $39 \%$ & Post Graduate & 72 & $36 \%$ \\
\hline Above 50 Years & 52 & $26 \%$ & $\begin{array}{l}\text { Professional } \\
\text { Degree }\end{array}$ & 84 & $42 \%$ \\
\hline Gender & Frequency & Percent & Marital Status & Frequency & Percent \\
\hline Male & 142 & $71 \%$ & Married & 116 & $58 \%$ \\
\hline Female & 58 & $29 \%$ & Unmarried & 84 & $42 \%$ \\
\hline \multicolumn{4}{|c|}{ Numbers of Respondents } & 200 & $100 \%$ \\
\hline
\end{tabular}

\section{Travel Choice}

In order to know the frequency of visits to the study area, it was found that $63 \%$ of respondents were first-time visitors, followed by $13 \%$ experiencing attractions for the second time, $6 \%$ were enjoying its third time and $18 \%$ respondents have experienced it more than three times. While knowing about the purpose of visiting Trijuginarayan, $38 \%$ answered religious and cultural purpose, $26 \%$ opted for rural experience, $21 \%$ for holiday purpose and $15 \%$ had other reasons. In response to the length of stay, $37 \%$ respondents preferred to stay single day, $38 \%$ were for two or three days, whereas $25 \%$ liked to spend three or more days three days. On inquiring about the sources of information, 50\% respondents were convinced by friends, $19 \%$ respondents were appraised by travel agents and newspaper/magazine, respectively and $12 \%$ sampled tourist came to know thorough tourist brochures. While obtaining details about the nature of visits it was noticed that $11 \%$ were alone, $39 \%$ came with spouse, $27 \%$ preferred to visit with family, $16 \%$ visited with friends/classmates and $7 \%$ travelled with friends and relatives. As destination comes under offbeat location, $36 \%$ respondents preferred to come with their own vehicles whereas $64 \%$ used public transport. 
Table 2. Travel Information

\begin{tabular}{|c|c|c|c|c|c|}
\hline Visit Frequency & Frequency & Percent & Source of Information & Frequency & Percent \\
\hline First time & 126 & $63 \%$ & Friends & 100 & $50 \%$ \\
\hline Second time & 26 & $13 \%$ & Travel Agent & 38 & $19 \%$ \\
\hline Third time & 12 & $6 \%$ & Brochure & 24 & $12 \%$ \\
\hline Fourth time or more & 36 & $18 \%$ & Newspaper/Magazine & 38 & $19 \%$ \\
\hline Purpose of Visit & Frequency & Percent & Companion & Frequency & Percent \\
\hline Religion and Culture & 76 & $38 \%$ & Alone & 22 & $11 \%$ \\
\hline Rural Experience & 52 & $26 \%$ & Couples (Spouse) & 78 & $39 \%$ \\
\hline Holidays & 42 & $21 \%$ & Family & 54 & $27 \%$ \\
\hline Other Reasons & 30 & $15 \%$ & Friends/Classmates & 32 & $16 \%$ \\
\hline Length of Stay & Frequency & Percent & $\begin{array}{l}\text { Others (Relatives, } \\
\text { parents) }\end{array}$ & 14 & $7 \%$ \\
\hline One day & 74 & $37 \%$ & Mode of Travel & Frequency & Percent \\
\hline Two or Three days & 76 & $38 \%$ & Own Vehicle & 72 & $36 \%$ \\
\hline More than three days & 50 & $25 \%$ & Public Transport & 128 & $64 \%$ \\
\hline \multicolumn{4}{|c|}{ Total Number of Respondents } & 200 & 100 \\
\hline
\end{tabular}

\section{Importance-Performance Mean of Destination Attributes}

Table 3 shows importance and performance mean of 28 destination attributes are categorized into four major categories, namely weather and accessibility, uniqueness of the destination, quality of tourist facilities and tourist motivational factor. Results presented in table 3 also indicate that some attributes had better performance than their perceived importance, while some of them were vice versa. Data summarized in table 3 reveals that 'weather and accessibility' factor had importance mean 3.98 and performance mean 3.28, resulting -0.70 mean difference. 'Uniqueness of destination' factor has importance mean 3.58 and performance mean 4.09, resulting mean difference of o.51. The importance mean is 3.64 , performance mean is 2.80 and corresponding mean difference is - 0.84 for 'quality of tourist facilities' factor. The mean difference of - 0.18 is calculated from importance mean (3.83) and performance mean (3.65) for 'tourist motivational factor'.

The mean scores of 28 attributes range from 3.10 to 4.24 , indicating that respondents ranked all these attributes importantly, more specifically, between 'very important' and 'extremely important'. The top three most important attributes were availability and adequacy of transportation facilities (4.24), completeness of roads and road signage to the destinations (4.11) and destination offers value for money (4.00), indicating that tourists perceived these attributes as the most important factors. However, variations of tourist attractions (3.10), uncrowded and unspoiled destination (3.10) and availability of competent tourist guide (3.29) have been given the less weightage. The mean scores of performance statements about tourists' perceptions of the performance of 28 attributes are also calculated in Table 3 . The mean scores of 28 statements range from 2.44 to 4.24. Compared to the importance of the perceptions, the perceptions of the performance were relatively low, indicating that the actual performance of the industry slightly lower than visiting tourist expectations. Tourists gave the highest ratings to wilderness and undisturbed nature (4.24), variation in tourist attractions (4.24) and pleasant weather and climate (4.13). Subsequently, the below average rankings were given by tourists to easy accessibility to hotels and lodges (2.44) and cleanliness and maintenance of public convenience (2.44). 
Table 3. Importance-Performance Mean of Destination Attributes

\begin{tabular}{|c|c|c|c|}
\hline Variables & Importance Mean & Performance Mean & Mean Difference \\
\hline Weather and Accessibility $(\alpha=0.798)$ & 3.98 & 3.28 & -0.70 \\
\hline Pleasant weather and climate & 3.96 & 4.13 & 0.17 \\
\hline The destination is free from air and noise pollution & 4.00 & 4.11 & 0.11 \\
\hline Availability and adequateness of transportation facilities & 4.24 & 2.88 & -1.36 \\
\hline Completeness of roads and road signage to destination & 4.11 & 3.00 & -1.11 \\
\hline Easy accessibility of hotels and lodges & 3.98 & 2.44 & -1.54 \\
\hline Telecommunication facilities near tourist destination & 3.60 & 3.12 & -0.48 \\
\hline Uniqueness of Destination ( $\alpha=0.843$ ) & 3.58 & 4.09 & 0.51 \\
\hline Tranquility and Panoramic view of natural environment & 4.00 & 4.11 & 0.11 \\
\hline Wilderness and undisturbed nature & 3.68 & 4.24 & 0.56 \\
\hline A rich spiritual and cultural heritage & 3.54 & 4.12 & 0.58 \\
\hline Spiritual attractions are well kept and restored & 3.48 & 3.98 & 0.50 \\
\hline Variety of tourist attractions & 3.10 & 4.24 & 1.14 \\
\hline Protected cultural and natural resources & 3.29 & 3.98 & 0.69 \\
\hline The destination is unique and authentic & 4.00 & 3.98 & -0.02 \\
\hline Quality of Tourist facilities $(\alpha=0.817$ ) & 3.64 & 2.80 & -0.84 \\
\hline Quality \& hygiene at tourist place, accommodation \& eateries & 3.92 & 2.68 & -1.24 \\
\hline Proper interpretation facilities & 3.84 & 3.00 & -0.84 \\
\hline Availability of competent tourist guide & 3.29 & 2.44 & -0.85 \\
\hline Maintenance of tourist attractions & 3.47 & 2.58 & -0.89 \\
\hline Cleanliness \& maintenance of public convenience facilities & 3.80 & 2.44 & -1.36 \\
\hline Availability of leisure and recreational activities & 4.00 & 3.24 & -0.76 \\
\hline Availability of quality souvenirs & 3.73 & 2.58 & -1.15 \\
\hline Uncrowded and unspoiled destination & 3.10 & 3.46 & 0.36 \\
\hline Tourist Motivational Factor $(\alpha=0.790)$ & 3.83 & 3.65 & -0.18 \\
\hline Low traffic and adequate parking facilities & 3.86 & 3.68 & -0.18 \\
\hline Well maintained pedestrian, parks and green areas & 3.58 & 3.10 & -0.48 \\
\hline Hospitality and friendliness of local people & 3.92 & 4.00 & 0.08 \\
\hline Safety and security & 4.00 & 4.12 & 0.12 \\
\hline Availability of information center & 3.88 & 3.24 & -0.64 \\
\hline The destination offers value for money & 4.00 & 3.58 & -0.42 \\
\hline Activity oriented tourism place for a whole year & 3.58 & 3.86 & 0.28 \\
\hline
\end{tabular}

\section{Importance Performance Analysis (IPA)}

In order to examine tourist satisfaction with destination attributes, mean scores of all attributes were plotted on the IPA matrix as shown in figure 3 (a-d). For each IPA approach matrix, placements of axes on the grid were calculated through the grand mean of the given factors. Tourists' perception and importance values were plotted on the four quadrant grid that were formed based on the mean scores of importance perception ratings. Each attribute was then assessed by locating in the appropriate quadrant. Each quadrant suggests a different response from the destination marketing strategy point of view. 


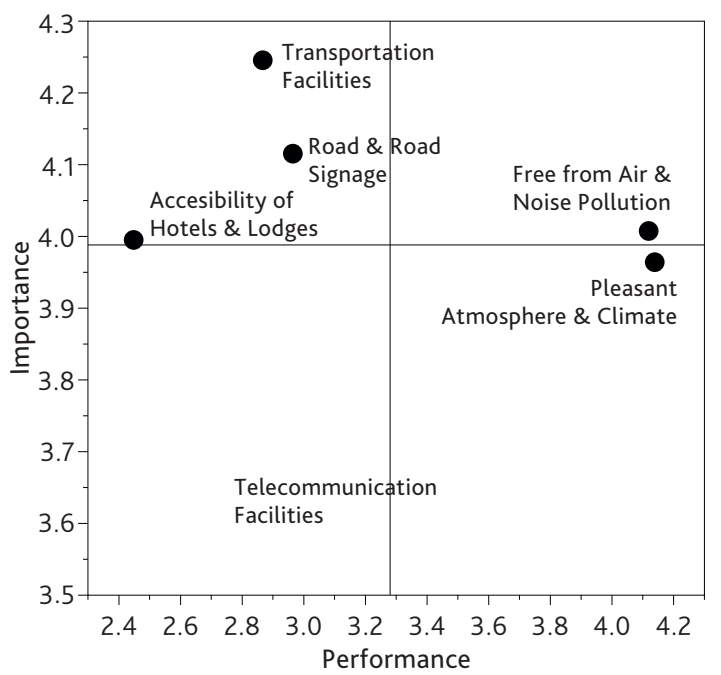

Fig 3 (a). Weather and Accessibility

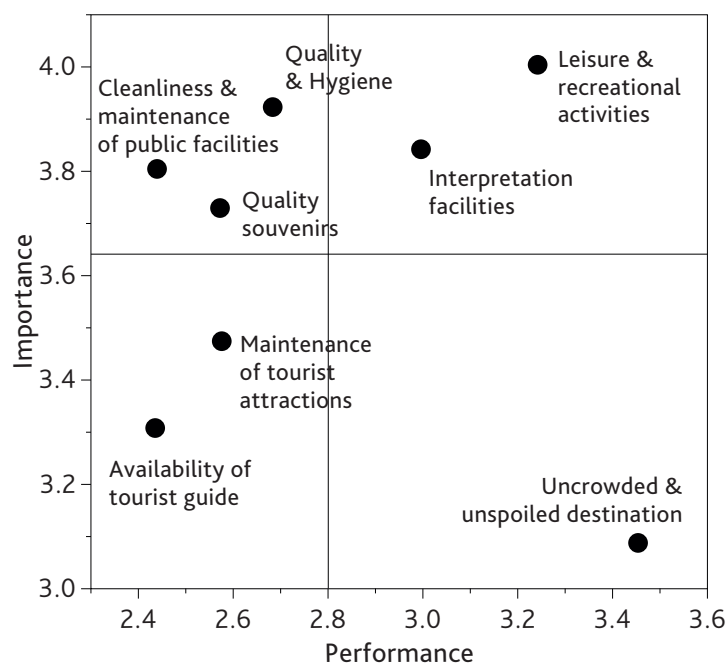

Fig 3 (c). Quality of Tourist Facilities

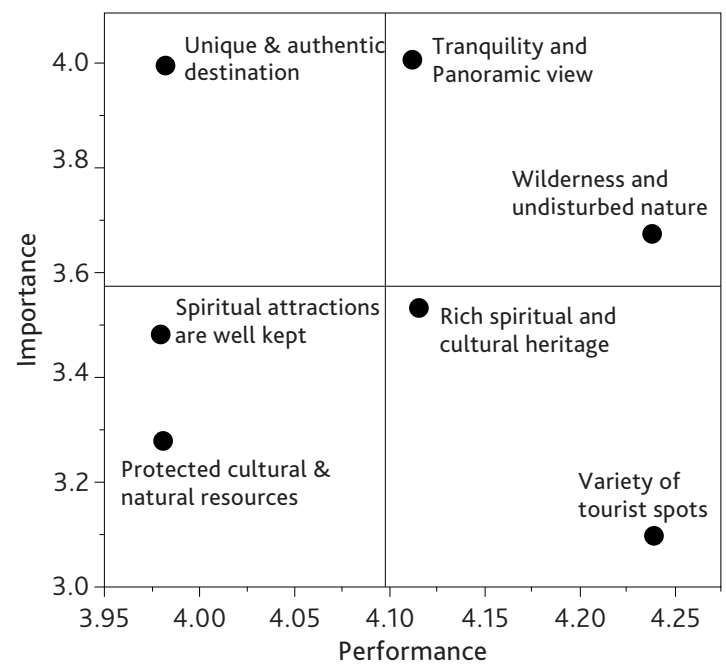

Fig 3 (b). Uniqueness of Destination

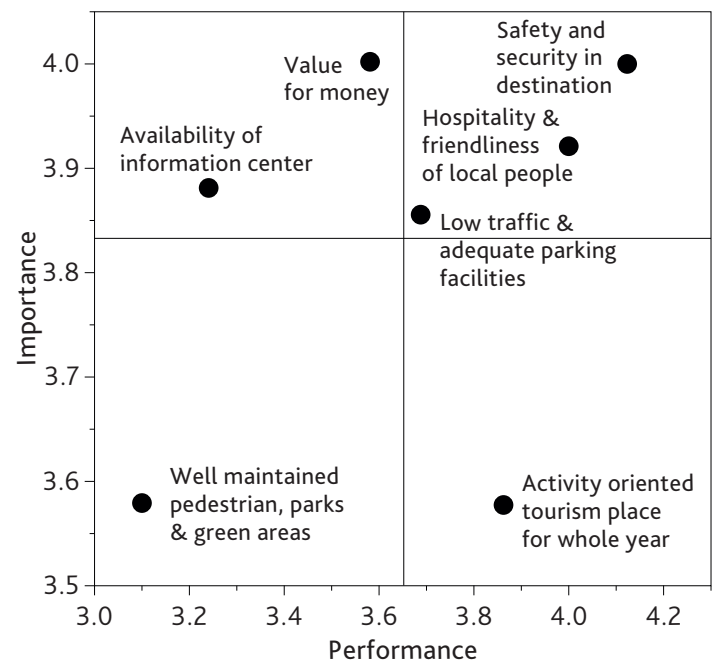

Fig 3 (d). Tourist Motivational Factors

\section{Weather and Accessibility}

Quadrant I is the Concentrate here quadrant and it includes three attributes: 'availability and adequacy of transportation, 'completeness of roads and road signages to destinations' and 'easy accessibility of hotels and lodges'. Tourists perceive the importance of these three attributes. However, the performance of these features was comparatively less appealing to tourists. Efforts are to be made to improve transportation and accommodation facilities for tourists since tourists are visiting the study area with all expectations. Quadrant II is the Keep up the good work quadrant and only one attribute, 'destination is free from air and noise pollution' was identified in this quadrant. This indicates that the performance of destination in this 
aspect is satisfactory and tourists were satisfied with the quality of the environment. Quadrant III is the Low priority quadrant and only 'telecommunication facilities near tourist spots' attribute is located in this. In the fourth possible overkill quadrant, 'pleasant weather and climate' attribute was identified only. This indicates that this attribute was rated as lower than the average in importance, and that the performance was higher than the average.

\section{Uniqueness of Destination}

Attributes of Concentrate here quadrant give management indication that is important to tourists, whereas the performance does not really match the expectations. Only single attribute, 'destination is unique and authentic', was identified in this quadrant. Although tourists perceive quite high importance to this attribute, the performance was not found satisfactory by them. In Keep up the good work quadrant two attributes 'tranquillity and panoramic view of the natural environment' and 'wilderness and undisturbed nature' were projected. It shows that tourists are satisfied with these attributes. In the third Low priority quadrant again, there were two attributes 'spiritual attractions are well kept and restored' and 'protected cultural and natural resources'. In the last Possible overkill quadrant, 'rich spiritual and cultural heritage' and 'variety of tourist spots' were identified. It indicates the satisfactory performance of the destination was given less weightage.

\section{Quality of Tourist Facilities}

Three attributes 'quality and hygiene of a tourist place, accommodation and eateries', 'cleanliness and maintenance of public convenience' and 'availability quality souvenirs' fell into Concentrate here quadrants. It shows that tourists' places have a relatively high importance of these features, but their expectations were not addressed. The second Keep up the good work quadrant included 'availability of leisure and recreational activities' and 'proper interpretation facilities at tourist spots' attributes. It indicates that tourists gave high importance to these attributes. 'Maintenance of tourist attractions' and 'availability of competent tourist guides' figured in the third Low priority quadrant, indicating the low importance of giving attributes. Only feature 'uncrowded and unspoiled destination' is placed in the possible overkill quadrant of low importance and high performance.

\section{Tourist Motivation}

Concentrate here quadrant includes two attributes 'availability of information center' and 'destination offers value for money' under which performance of the destination was not found satisfactory by tourists. Under Keep up the good work quadrant, three features named 'low traffic and adequate parking facilities', 'hospitality and friendliness of local people' and 'safety and security in destination' were identified. The performance of the study area in these attributes was good and the tourists were satisfied with this. As the feature 'well maintained pedestrian, parks and green areas' was identified in Low priority quadrant, there are possibilities that concerned attribute was of poor advantage. 'Activity oriented tourism place for whole year' attribute placed in possible overkill quadrant indicates the performance of destination in this low important feature is quite satisfactory and destination offers round the year tourism activities for tourists. 


\section{Discussion}

The present study area provides a conducive ambience for wellbeing, peace and self-actualization and has enough potential and availability of resources required to become a spiritual center. It also offers ample opportunities for adventure and outdoor recreational tourism activities including trekking, hiking, bird watching, rock-climbing, rappelling, paragliding, cycle safari and nature photography. Measuring tourist satisfaction level is important as it can serve as a barometer to ascertain 'quality' of tourism offerings and services. The results of the study provide insights on various attributes that have strong influence on tourists' satisfaction. Most of the tourists visiting the destination showed a relatively high importance and satisfaction with various attributes.

On comparing the perceived importance and actual performance of various attributes, it was observed that many tourists came to destination with higher expectations and left the region with varying level of satisfaction. All attributes of destination were classified in four categories: weather and accessibility, uniqueness of destination, quality of tourist facilities and tourist motivational factors. Results showed that the weather and accessibility was considered the most important by tourists, followed by tourist motivational factors, quality of tourist facilities and uniqueness of the destination. The given attributes were in between excellent to satisfactory level. It showed that perceived expectation of tourists for destination was good for categorization it as a unique destination, almost satisfactory for tourist motivational factor and poor of weather and accessibility, and quality of tourist facilities. Out of 28 attributes, the top three most important attributes were availability and adequacy of transportation facilities, structure of roads and road signage and value for money. In terms of performance, tourists gave the top ratings to wilderness and undisturbed nature, variety of tourist spots and pleasant weather and climate. The poor ratings were given to easy accessibility to hotels and lodges, cleanliness and maintenance of public convenience and availability of means of travel services.

In order to know the relationship between the perceived expectation and performance of all attributes under four categorizes, Importance-Performance Approach (IPA) was utilized. Concentrate here quadrant included nine attributes and it includes 'availability and adequateness of transportation facilities', 'completeness of roads and road signage', 'easy accessibility to hotels and lodges', 'unique and authentic tourist destination', 'quality of and hygiene at tourist places including accommodation and eateries outlets', 'cleanliness and maintenance of public convenience', 'availability of quality souvenirs', 'provision of information centre' and 'destination offers value for money'. In view of the given attributes, it is revealed that the destination is not properly developed and maintained for tourists. The attractions are supported by poor tourism infrastructure and available amenities and facilities are in deprived state. Since middle aged, elderly persons and married couples visit the destination along with family members, substantial effort must be put into action for improving roads, signage, transportation facilities and other primary tourism services like accommodation units and catering outlets. Normally for an upcoming tourist destination, local means of transportation and infrastructure to improve reachability of tourism destinations, improving accommodation and catering facilities, conformity to cleanliness and hygiene and updated destination information are of great significance. Efforts are to be made to inculcate all the above-referred issues in placing tourist destination as spiritual and adventurous tourist location.

Keep up the good work quadrant comprised eight attributes, namely 'destination is free from air and noise pollution', 'tranquillity and panoramic view of the natural environment', 'wilderness and undisturbed nature', 'availability of leisure and recreational activities', 'proper 
interpretation facilities at tourist spots', 'low traffic and adequate parking facilities', 'hospitality and friendliness of local people' and 'safety and security in destination'. The performance of destination in the above aspects is conducive and tourists were satisfied with them. But while reviewing the parameter related to 'proper interpretation facilities', 'availability of leisure and recreational activities' and 'low traffic and adequate parking facilities' attributes, performance was rated lower than the importance. In view of this, the destination must pay attention to adequate interpretation of tourist attractions as well as making provision of parking facilities and planning and development of leisure and recreational activities, which may provide more satisfaction and may offer an exciting offering to tourists. In order to compete with other emerging mountainous destination, Trijuginarayan must preserve its unique natural environment suitable for peace, well-being and self-actualization. Since infrastructure development is a major concern for the destination, this seems a challenge for local tourism authorities, government and other stakeholders to develop an area without affecting destination features of competitive advantage.

Six attributes were identified in Low priority quadrant. These were 'telecommunication facilities near tourist spots', 'spiritual attractions are well kept and restored', 'protected cultural and natural resources', 'maintenance of tourist attractions', 'availability of competent tourist guide', and 'well maintained pedestrian, parks and green areas'. These attributes were rated as below average for both importance and performance. The performance of each attribute was not regarded as satisfactory by tourists, and has not been perceived as very important factors by tourists. This implies that the study area should not use many resources in this quadrant. Stakeholders responsible for the development of destination must understand that although attributes of this quadrant are not of that significance in tourist satisfaction, these can't be put aside. Because the mean score of these attributes was average in nature, thus much space is available for further improvement otherwise there are possibilities of negative impact and decrease performance. Possible overkill quadrant contained five attributes, namely 'pleasant atmosphere and climate', 'rich spiritual and cultural heritage', 'variety of tourist spots', 'uncrowded and unspoiled destination' and 'activity oriented tourism place for the whole year'. These attributes were rated as lower than the average in importance, and that the performance of them in this area was higher than the average. Tourists have got the impression that Trijuginarayan has all features to make it as a tourist attraction for spiritual and pilgrimage destination with 'various activities oriented tourist spots', 'uncrowded and unspoiled destination with pleasant atmosphere' but efforts should be made towards retaining the present status and maintaining high standards without over-utilizing resources.

Uttarakhand Tourism Development Board, as referred earlier one of the main stakeholders to promote tourism in the state, is making ceaseless efforts to promote spiritual tourism in such a way that pilgrims and other nature of tourists having spiritual motivation may be provided the best possible opportunities to avail spiritual tourism experiences. Efforts of local tourism development authorities are underway to develop a couple of tourist sites in the surroundings of the study area. These sites will be linked by hassle free pedestrian pathways with the provisions of some viewpoints, open spaces and hygienic eateries. In order to improve accommodation facilities, a tourist rest house operated by Garhwal Mandal Vikas Nigam, an autonomous body of Uttarakhand State is in operation. The Board is promoting home-stay accommodation by identifying people willing to convert their houses partially into lodges with necessary provisions of food and beverages to tourists. For improving hygiene and sanitation, Department of Health and Sanitation of Uttarakhand has made the provision of some units of public convenience facilities. To improve language and hospitality skills, some NGOs are 
extending short term courses to local people so that they can deliver adequate services to tourists and join tourism and hospitality traded as a profession for self-reliance. Short and longterm courses on different aspects of tourism and hospitality ranging from 7 to 30 days duration may be designed for local youths in collaboration with Indian Institute of Entrepreneurship, educational institutions and Universities.

Better accommodation facilities, road and transportation and cleanliness and hygiene in tourism products and facilities are important factors for ensuring tourist satisfaction. Necessary tourist facilities must be available for tourists to enjoy the destination and to make a desired behavioral intention to revisit and recommend the destination to others. Another significant area of increasing satisfaction is provision of tourist information. Providing better information about the conditions of infrastructure, transportation and accommodation, spiritual and cultural background, geographical and historical information, local events and nature of available tourism products and attractions could help tourists be better prepared for what they may encounter. Tourist information centers ensure better of quality of presentation of information about this emerging tourist destination in terms of the well-informed tourist map, signage, models and displays, up-to-date photos, pamphlets and audio-visual presentations.

\section{Conclusion}

Trijuginarayan has many spiritual and adventure tourism opportunities, potential to promote tourism in its surroundings. But the destination has failed to project its existing potential. The background of tourists' motivation to the destination is the diversity of its cultural and spiritual values, pleasant weather and climatic conditions and variety of tourism products. The hospitality offered by local people with the provision of safety and security made a strong tourist choice toward the destination. The critical issues that received negative feedback from tourists were inadequate roads and proper signage, poor travel connectivity, sub-standard accommodation facilities, poor quality of hygiene, maintenance of public convenience and non-existent information centers. Available amenities and facilities of the destination need significant improvement. Accommodation is another essential component that needs upgradation including adding the requirements of the standard level of room and room services. Tourism service providers need to focus on quality of products and services offered and pay more attention to cleanliness and maintenance of accommodation and eating outlets. By making the provision of sanitary requirements in the area and even imposing fines for littering behavior of tourism stakeholders, tourism authorities can start the process of clean environment and raise awareness of hygiene to both locals and tourists. Uttarakhand Tourism Development Board should develop liaising with other departments including forest and wildlife, public works, health and sanitation to sublet better products and services to tourists and have a better plan to improve environmental friendly tourist destination. 


\section{References}

Aksu, A., Icigen, E.T. and Ehtiyar, R. 2010. A comparison of tourist expectations and satisfaction: A case study from Antalya region of Turkey. Turizam, 14 (2), 66-77.

Aktas, A., Cevirgen, A. and Toker, B. 2009. Assessing holiday satisfaction of German and Russian tourists visiting Alanya. Tourism and Hospitality Management, 15 (1), 1-12.

Alegre, J. and Garau, J. 2010. Tourist satisfaction and dissatisfaction. Annals of Tourism Research, 37 (1), 52-73.

Bagri, S. C., Babu, S., and Kukreti, M. 2010. Human resource practices in hotels: A study from the tourist state of Uttarakhand, India. Journal of Human Resources in Hospitality and Tourism, 9 (3), 286-299.

Bagri, S.C. and Babu, S. 2011. Historical development of tourism education in India: The case of the Himalayan state of Uttarakhand. Journal of Tourism, 12 (1), 39-58.

Bagri, S.C., Babu, S. and Bhatt, V.P. 2013. Innovation and competitiveness in Ecotourism: A view from the Koti-Kanasar, Indroli, Patyur circuit in Uttarakhand Himalaya, India. Journal of Tourism, 14 (1), 109-137.

Bagri, S.C., Babu, S., Kukreti, M. and Smith, S. 2011. Human capital decisions and employee satisfaction at selected hotels in India. FIU Hospitality Review, 29 (2), 104-120.

Baker, D.A. and Crompton, J. (2000). Quality, satisfaction and behavioral intentions. Annals of Tourism Research, 27 (3), 785-804.

Bigne, J. E., Sanchez, I., and Andreu, L. 2009. The role of variety seeking in short and long run revisit intentions in holiday destinations. International Journal of Culture, Tourism and Hospitality Research, 3 (2), 103-115.

Bigne, J. E., Sanchez, M. I., and Sanchez, J. 2001. Tourism image, evaluation variables and after purchase behaviour: Inter-relationship. Tourism Management, 22 (6), 607-616.

Chen, C. and Chen, F. 2010. Experience quality, perceived value, satisfaction and behavioral intentions for heritage tourists. Tourism Management, 31 (1), 29-35.

Chen, $\mathrm{Xu}$. 2013. The modified importance-performance analysis method and its application in tourist satisfaction research. Tourism Tribune, 28 (11), 59-66.

Chi, C.G., and Qu, H. 2008. Examining the structural relationships of destination image, tourist satisfaction and destination loyalty: An integrated approach. Tourism Management, 29 (4), 624-636.

Christou, P. and Saveriades, A. 2010. The use of enthnography to explore tourist satisfaction antecedents. Tourismos: An International Multidisciplinary Journal of Tourism, 5 (1), 89-100.

Cracoli, M. F. and Nijkamp, P. 20o8. The attractiveness and competitiveness of tourist destinations: A study of Southern Italian regions. Tourism Management 30, 336-344.

Dmitrovic, T., Cvelbar, K. L., Kolar, T., Brencic, M. M., Ograjensek, I., Zabkar, V. 2009. Conceptualization tourist satisfaction at the destination level. International Journal of Culture, Tourism and Hospitality Research, 3 (2), 116-126.

Huang, A. and Xiao, H. 20oo. Leisure-based tourist behavior: A case study of Changchun. International Journal of Contemporary Hospitality Management, 12 (3), 210-214.

Hui, T.K., Wan, D. and Ho, A. 2007. Tourists' satisfaction, recommendation and revisiting Singapore. Tourism Management, 28, 965-975.

Janes, P. and Wisnom, M.S. 2003. The use of importance-performance analysis in the hospitality industry: A comparison of practices. Journal of Quality Assurance in Hospitality and Tourism, 4 (1/2), 23-45. 
Kala, D. and Bagri, S.C. 2014. An exploratory study of managerial attitude towards performance measurement in hotels of Uttarakhand state of India. International Journal of Qualitative Research in Services, 1 (4), 276-291.

Kaul, H., and Gupta, S.2009. Sustainable tourism in India. Worldwide Hospitality and Tourism Themes, 1 (1), 12-18.

Khuong, M.N. and Ngoc, N.T. 2014. Factors affecting tourist destination satisfaction through mediating variable of perceived service quality - A study in Ho Chi Minh City, Vietnam. Proceedings of 5 th International Conference on Business and Economic Research, Sarawak, Malaysia, 312-326.

Kozak, M. 2001. Comparative assessment of tourist satisfaction with destinations across two nationalities. Tourism Management, 22 (4), 391-401.

Kozak, M. 2003. Measuring comparative destination performance: A study in Spain and Turkey. Journal of Tourism and Travel Marketing, 13 (3), 83-110.

Kozak, M. and Rimmington, M. 20oo. Tourist satisfaction with Mallorca, Spain, as an off-season holiday destination. Journal of Travel Research, 38 (3), 260-269.

Lai, I.K.W. and Hitchcock, M. 2015. Importance-performance analysis in tourism: A framework for researchers. Tourism Management, 48 (June), 242-267.

Lee, T. H. 2009. A structural model for examining how destination image and interpretation services affect future visitation behavior: A case study of Taiwan's Taomi eco-village. Journal of Sustainable Tourism, 17 (6), 727-745.

Mahar, S. and Bagri, S.C. 2010. Tourism in the Himalayas: An Evaluation of Tourist Perception, Expectation Quotient and Satisfaction Level in the Bhilangana River Valley of Uttarakhand State, Journal of Tourism, 11(1), 21-42.

Marcussen, C.H. 2011. Determinants of tourist satisfaction and intention to return. Tourism An International Interdisciplinary Journal, 59 (2), 203-221.

Martilla, J.A. and James, J.C. 1977. Importance-performance analysis. Journal of Marketing, 41 (1), 77-79.

Matzler, K., Sauerwein, E. and Heischmidt, K.A. 2003. Importance-performance analysis revisited: The role of the factor structure of customer satisfaction. Service Industries Journal, 23 (2), 112-129.

McDowall, S. 2010. International tourist satisfaction and destination loyalty: Bangkok, Thailand. Asia Pacific Journal of Tourism Research, 15 (1), 21-42.

Medina-Muñoz, D.R. and Medina-Muñoz, R.D. 2014. The attractiveness of Wellness destinations: An importance-performance-satisfaction approach. International Journal of Tourism Research, 16 (6), 521-533.

Meng, F., Tepanon, Y. and Uysal, M. 2008. Measuring tourist satisfaction by attribute and motivation: The case of a nature-based resort. Journal of Vacation Marketing, 14 (1), 41-56.

Neal, J. D. and Gursoy, D. 2008. A multifaceted analysis of tourism satisfaction. Journal of Travel Research, 47 (August), 53-62.

Oh, H. 2001. Revisiting importance-performance analysis. Tourism Management, 22 (6), 617627.

Osti, L., Disegna, M. and Brida, J.G. 2012. Repeat visits and intentions to revisit a sporting event and its nearby destinations. Journal of Vacation Marketing, 18, 31-42.

Ozturk, B. A. \& Qu, H. 2008. The impact of destination images on tourists' perceived value, expectations and loyalty. Journal of Quality Assurance in Hospitality and Tourism, 9 (4), 275-297. 
Pizam, A., Neumann, Y. and Reichel, A. 1978. Dimensions of tourist satisfaction with a destination area. Annals of Tourism Research, 5 (3), 314-332.

Prayag, G. and Ryan, C. 2012. Antecedents of tourists' loyalty to Mauritius: The role and influence of destination image, place attachment, personal involvement, and satisfaction. Journal of Travel Research, 51 (3), 342-356.

Pritchard, M. 2003. The attitudinal and behavioral consequences of destination performance. Tourism Analysis, 8 (1), 61-73.

Reuter, C. and Pechlaner, H. 2012. Sustainable trekking tourism development with a focus on product quality assessment - Two cases from Indian Himalayas. Journal of Tourism, 13 (2), 1-21.

Singh, A. and Singh, R. 2009. Factors affecting wildlife tourism and satisfaction of wildlife tourist in Jim Corbett National Park. Tourism: Theory and Practice, 7 (2), 50-76.

Singh, R. B., Mal, S., and Kala, C. P. 2009. Community responses to mountain tourism: A case in Bhyundar valley, Indian Himalaya. Journal of Mountain Science, 6 (4), 394-404.

Singh, T. V. 2005. Nature's Unique Cybernetics: The Valley of Flowers. Tourism Recreation Research, 30 (3), 1-3.

Thapliyal, D.D. 2006. Himalayas: In the Pilgrimage of Inside. Winsar Publishing Co., Dehradun.

Torres-Sovero, C., González, J.A. Martín-López, B. and Kirkby, C.A. 2012. Social-ecological factors influencing tourist satisfaction in three ecotourism lodges in the south-eastern Peruvian Amazon. Tourism Management, 33, 545-552.

Uttarakhand Tourism Development Master Plan, 2007 - 2022. 2008. Government of India, Government of Uttarakhand, United Nations Development Program and World Tourism Organization, April, 2008.

Wade, D. and Eagles, P. 2003. The use of importance-performance analysis and market segmentation for tourism management in parks and protected areas: An application to Tanzania's National Parks. Journal of Ecotourism, 2 (3), 196-212.

Wang, S. and Qu, H. 2006. A study of tourist satisfaction determinants in the context of the Pearl River Delta sub-regional destinations. Journal of Hospitality and Leisure Marketing, $14(3), 49-63$.

Wang, X., Zhang, J., Gu, C., and Zhen, F. 2009. Examining antecedents and consequences of tourist satisfaction: A structural modeling approach. Tsinghua Science and Technology, 14 (3), 397-406.

Yoon, Y. and Uysal, M. 2005. An examination of the effects of motivation and satisfaction on destination loyalty: a structural model. Tourism Management, 26, 45-56.

Yuksel, A. 2001. Managing customer satisfaction and retention: A case of tourist destinations, Turkey. Journal of Vacation Marketing, 7 (2), 153-168.

Zabkar, V., Brenčič, M. and Dmitrović, T. 2010. Modelling perceived quality, visitor satisfaction and behavioural intentions at the destination level. Tourism Management, 31, 537-546.

Zhang, H.Q. and Chow, I. 2004. Application of importance-performance model in tour guides' performance: Evidence from Mainland Chinese outbound visitors in Hong Kong. Tourism Management, 25 (1), 81-91. 